\title{
Drug-induced subacute cutaneous lupus erythematosus caused by amlodipine
}

\section{Polekowy podostry skórny toczeń rumieniowaty indukowany amlodypiną}

\author{
Agata Kozłowska', Zdzisław Woźniak², Joanna Maj', Rafał Białynicki-Birula' \\ 'Department of Dermatology, Venereology and Allergology, Wroclaw Medical University, Poland \\ 2Department of Pathomorphology, Wroclaw Medical University, Poland \\ 'Katedra i Klinika Dermatologii, Wenerologii i Alergologii Uniwersytetu Medycznego we Wrocławiu, Polska \\ ${ }^{2}$ Katedra i Zakład Patomorfologii Uniwersytetu Medycznego we Wroctawiu, Polska
}

Dermatol Rev/Przegl Dermatol 2018, 105, 298-306 DOI: https://doi.org//0.5। |4/dr.2018.75585

\author{
CORRESPONDING AUTHOR/ \\ ADRES DO KORESPONDENCJI: \\ dr hab. n. med. \\ Rafał Białynicki-Birula \\ Katedra i Klinika Dermatologii, \\ Wenerologii i Alergologii \\ Uniwersytet Medyczny \\ we Wrocławiu \\ ul. Chałubińskiego 1 \\ 50-368 Wrocław, Polska \\ tel.: +48601990167 \\ faks: +48713270942 \\ e-mail: rafal.bialynicki-birula@ \\ umed.wroc.pl
}

\begin{abstract}
Introduction. Drug-induced subacute cutaneous lupus erythematosus is a variant of lupus caused by exposure to certain drugs. It presents as annular or psoriasiform lesions located in regions which are exposed to UV radiation.

Objective. To report a case of subacute cutaneous lupus erythematosus induced by amlodipine.

Case report. A 78-year-old woman was admitted to our department with annular erythematous lesions which had appeared 5 months earlier on the upper extremities and trunk. Six months prior to the admission, amlodipine was added to the cardiac drugs previously used by the patient. The clinical findings and results of additional diagnostic tests suggested the diagnosis of drug-induced subacute cutaneous lupus erythematosus. Amlodipine was discontinued and adjuvant treatment was introduced, resulting in a significant improvement in skin condition.

Conclusions. In cases of subacute cutaneous lupus erythematosus, particularly those developing in patients aged 50 and older drugs, including amlodipine should always be considered as possible causative factors. A detailed analysis of medications used by such patients is necessary to determine the potential of the drugs to induce lesions and the time frame during which such lesions typically arise.
\end{abstract}

\section{STRESZCZENIE}

Wprowadzenie. Polekowy podostry skórny toczeń rumieniowaty jest odmianą tocznia, w której wskutek ekspozycji na niektóre leki dochodzi do powstania wykwitów obrączkowatych lub łuszczycopodobnych $\mathrm{w}$ okolicach eksponowanych na promieniowanie ultrafioletowe.

Cel pracy. Przedstawienie przypadku podostrego skórnego tocznia rumieniowatego indukowanego amlodypiną.

Opis przypadku. Kobieta 78-letnia została przyjęta na oddział z powodu rumieniowych zmian o obrączkowatym kształcie, które pojawiły się 5 miesięcy wcześniej na kończynach górnych oraz tułowiu. Sześć miesięcy przed przyjęciem do Kliniki do stosowanych wcześniej przez 
pacjentkę leków kardiologicznych dołączono amlodypinę. Obraz kliniczny i wyniki badań dodatkowych świadczyły o rozpoznaniu polekowego podostrego skórnego tocznia rumieniowatego. Odstawiono amlodypinę i wdrożono leczenie wspomagające, po czym uzyskano istotną poprawę stanu miejscowego.

Wnioski. W przypadkach podostrego skórnego tocznia rumieniowatego, zwłaszcza powstającego u pacjentów po 50. roku życia, należy zawsze rozważyć tło polekowe, $w$ tym rolę sprawczą amlodypiny. U tych pacjentów wskazane jest dokładne przeanalizowanie stosowanych leków pod kątem ich potencjału oraz przedziału czasowego wyzwalania objawów.

Key words: drug-induced subacute cutaneous lupus erythematosus, amlodipine.

Słowa kluczowe: polekowy podostry skórny toczeń rumieniowaty, amlodypina.

\section{INTRODUCTION}

Subacute cutaneous lupus erythematosus (SCLE) was first described as a distinct non-scarring subtype of cutaneous lupus erythematosus (CLE) by Sontheimer et al. in 1979 [1]. SCLE accounts for $10-15 \%$ of CLE cases [2]. It is 3-4 times more common in women, especially young and middle-aged, with the peak incidence between the ages of 30 and 40, estimated to be $0.6 / 100,000$ population/year $[3,4]$. Clinically, SCLE produces two main types of skin lesions: annular/polycyclic (42\% of cases) and psoriasiform/ papular scaly (39\% of cases), located symmetrically in sunlight-exposed areas, primarily on the lateral surfaces of the neck, chest and upper back, extensor surfaces of upper extremities and dorsal hands [3]. Facial skin is less commonly involved.

Subacute cutaneous lupus erythematosus typically runs a chronic course, with periods of exacerbation and remission. Skin lesions resolve without scarring, leaving behind hypopigmented patches or hyperpigmentations [1]. Antinuclear antibodies (ANA) are positive in $60-80 \%$ of patients, however anti-Ro/ SS-A antibodies, found in 70-90\% of patients, are generally recognized as the serological marker of SCLE. Anti-La/SS-B antibodies are less common (30-50\%) [5-7]. In $60 \%$ of patients direct immunofluorescence (DIF) of skin lesions shows deposits of immunoglobulins (mainly IgG and IgM) and/or complement components at the dermoepidermal junction. However, a negative lupus band test (LBT) of skin lesions does not exclude the diagnosis of SCLE [8]. Similarly to other forms of CLE, LBT is negative in pathologically unaltered skin [9]. The main factor responsible for inducing and exacerbating skin lesions secondary to SCLE is exposure to light, both natural sunlight and

\section{WPROWADZENIE}

Podostry skórny toczeń rumieniowaty (subacute cutaneous lupus erythematosus - SCLE) został po raz pierwszy opisany jako odrębny, niebliznowaciejący podtyp skórnego tocznia rumieniowatego (cutaneous lupus erythematosus - CLE) w 1979 r. przez Sontheimera i wsp. [1]. Stanowi on 10-15\% przypadków CLE [2]. Występuje 3-4 razy częściej u kobiet, zwłaszcza młodych i w średnim wieku, a szczyt zachorowalności, którą szacuje się na 0,6/ 100000 rocznie, przypada między 30. a 40. rokiem życia $[3,4]$. W obrazie klinicznym występują dwie główne odmiany zmian skórnych: obrączkowate, policykliczne (42\% przypadków) oraz łuszczycopodobne, grudkowo-złuszczające (39\% przypadków), zlokalizowane symetrycznie w okolicach eksponowanych na światło słoneczne, głównie na bocznych powierzchniach szyi, na klatce piersiowej, górnej części pleców, wyprostnej powierzchni kończyn górnych oraz na grzbietach rąk [3]. Rzadziej dochodzi do zajęcia skóry twarzy.

Podostry skórny toczeń rumieniowaty ma charakter przewlekły, z okresami zaostrzeń i remisji. Zmiany skórne ustępują bez bliznowacenia z pozostawieniem plam hipopigmentacyjnych lub przebarwień [1]. Przeciwciała przeciwjądrowe (antinucelar antibodies - ANA) są dodatnie u 60-80\% pacjentów, jednak za serologiczny marker SCLE uznaje się przeciwciała anty-Ro/SS-A, które są obecne u 70-90\% pacjentów. Rzadziej występują przeciwciała anty-La/SS-B (30-50\%) [5-7]. U 60\% pacjentów $\mathrm{w}$ bezpośrednim badaniu immunofluorescencyjnym ze zmian skórnych (direct immunofluorescence - DIF) obserwuje się złogi immunoglobulin (głównie IgG, IgM) i/lub składowych dopełniacza na granicy skórno-naskórkowej. Jednak ujemny wynik lupus band test (LBT) ze zmian skórnych nie wyklucza rozpoznania SCLE [8]. Podobnie jak w innych postaciach CLE, w skórze niezmienionej 
artificial sources of UV light [5]. Probably one-third of all SCLE cases are drug-induced [7].

\section{OBJECTIVE}

To report and discuss a case of drug-induced SCLE caused by amlodipine.

\section{CASE REPORT}

A 78-year-old woman was admitted to the Department for the diagnosis and treatment of annular erythematous skin lesions. The first lesions appeared 5 months prior to the admission, involving the skin on the extensor surfaces of the forearms, the chest and upper back. The patient had chronic coronary disease. Five years previously, she also had a non-ST segment elevation myocardial infarction (NSTEMI) and angioplasty of the right coronary artery and circumflex branch of the left coronary artery with the implantation of drug-eluting stents (DES). Since that time, the patient had used acetylsalicylic acid (75 mg/day), metoprolol (47.5 mg/day), valsartan ( $80 \mathrm{mg} /$ day) and atorvastatin ( $20 \mathrm{mg} /$ day). A month before the appearance of skin lesions amlodipine at a dose of $5 \mathrm{mg} /$ day was added to the therapeutic regimen.

On the day of admission to the Department, the patient presented with confluent, sharply marginated, infiltrated erythematous lesions with an annular pattern located on dorsal hands, extensor surfaces of the upper extremities, décolletage and back (fig. 1). The lesions were accompanied by severe pruritus (Numerical Rating Scale score 7/10). As the patient reported, the lesions exacerbated following exposure to sunlight. chorobowo LBT jest ujemny [9]. Głównym czynnikiem inicjującym oraz zaostrzającym zmiany skórne w przebiegu SCLE jest ekspozycja na światło - zarówno naturalne światło słoneczne, jak i sztuczne źródła światła ultrafioletowego [5]. Prawdopodobnie 1/3 przypadków SCLE ma etiologię polekową [7].

\section{CEL PRACY}

Przedstawienie i omówienie przypadku SCLE indukowanego amlodypiną.

\section{OPIS PRZYPADKU}

Kobieta 78-letnia została przyjęta do Kliniki w celu rozpoznania i leczenia rumieniowych zmian skórnych o obrączkowatym kształcie. Pierwsze zmiany pojawiły się u pacjentki 5 miesięcy przed przyjęciem w obrębie wyprostnej powierzchni przedramion, na skórze klatki piersiowej oraz górnej części pleców. Pacjentka chorowała na przewlekłą chorobę wieńcową. Dodatkowo 5 lat wcześniej przebyła zawał serca bez uniesienia odcinka ST (non-ST segment elevation myocardial infarction - NSTEMI) i angioplastykę prawej tętnicy wieńcowej oraz gałęzi okalającej lewej tętnicy wieńcowej z implantacją stentów uwalniających lek (drug eluting stent - DES). Od tego czasu stosowała kwas acetylosalicylowy (75 mg/dobę), metoprolol (47,5 mg/dobę), walsartan ( $80 \mathrm{mg} /$ dobę) oraz atorwastatynę (20 mg/dobę). Miesiąc przed wystąpieniem zmian skórnych do leczenia włączono dodatkowo amlodypinę $\mathrm{w}$ dawce $5 \mathrm{mg} /$ dobę.

W dniu przyjęcia do Kliniki na skórze grzbietowej powierzchni rąk, wyprostnej powierzchni kończyn górnych, skórze klatki piersiowej w okolicy mostka oraz

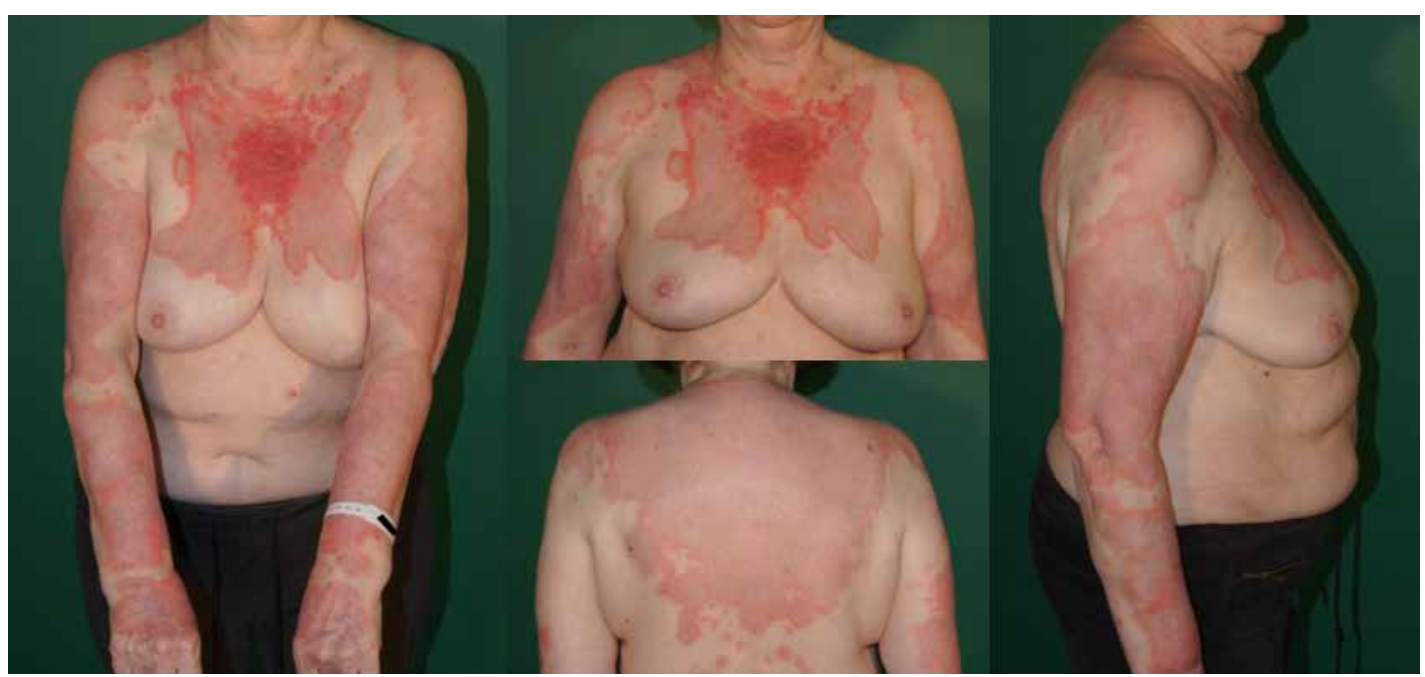

Figure I. Confluent, annular infiltrated erythematous lesions located on the skin of the upper limbs and the upper part of the trunk (on admission)

Rycina I. Zlewne, rumieniowo-naciekowe zmiany o obrączkowatym kształcie zlokalizowane na skórze kończyn górnych oraz górnej części tułowia (obraz w dniu przyjęcia) 
Figure 2. Skin specimen with marked thinning of the epidermis and orthokeratosis. Features of vacuolar degeneration and isolated cytoid bodies present in the basal layer. Abundant, diffuse and perivascular lymphocytic infiltrate visible in the dermis

Rycina 2. Fragment skóry ze znacznie ścieńczałym naskórkiem i ortokeratozq. W warstwie podstawnej obecne cechy zwyrodnienia wodniczkowego oraz pojedyncze ciałka cytoidalne. W skórze właściwej stosunkowo obfity, rozproszony i okołonaczyniowy naciek limfocytarny
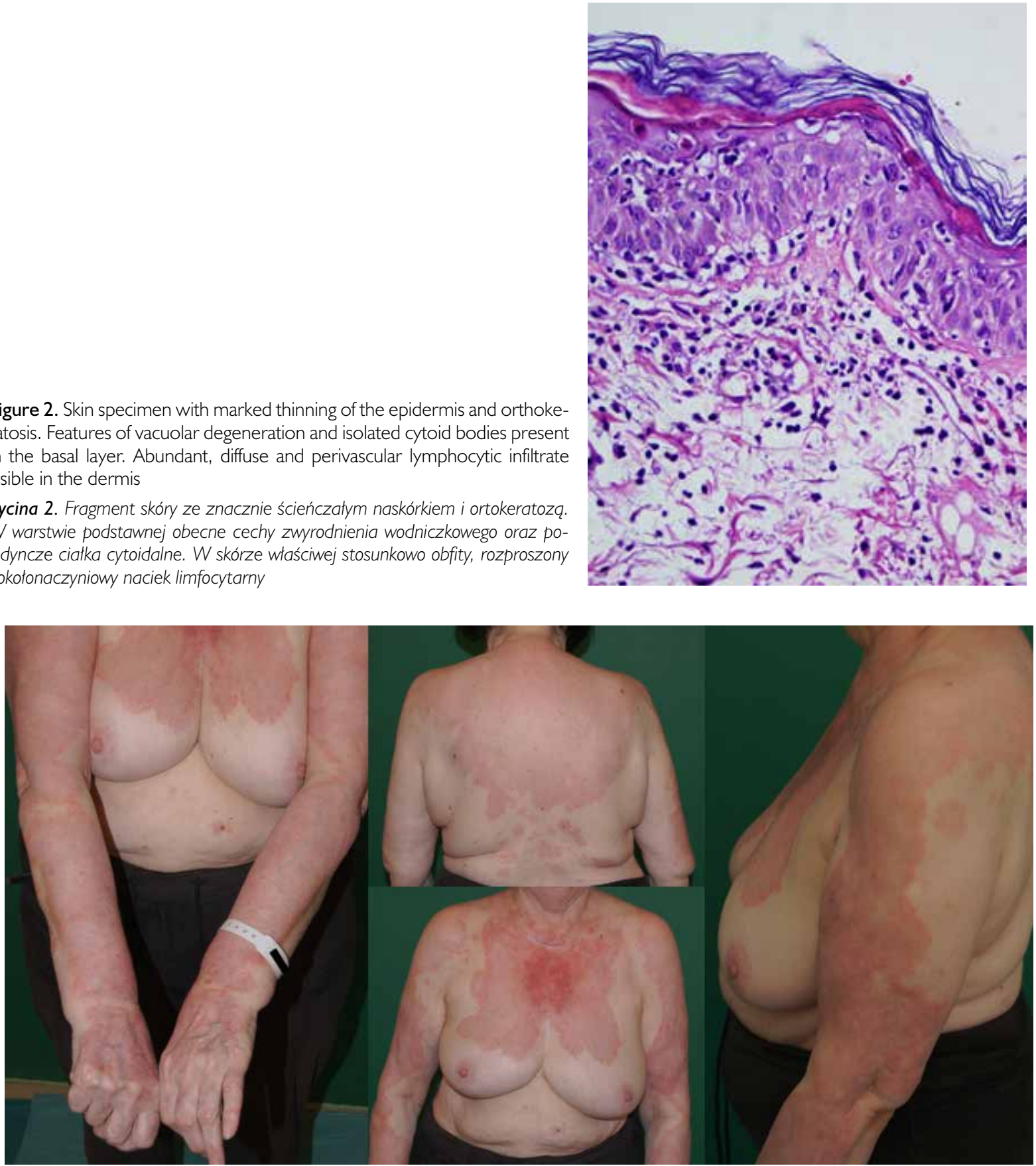

Figure 3. Cutaneous lesions during therapy ( 2 weeks after the initiation of treatment)

Rycina 3. Obraz zmian skórnych w trakcie terapii (2 tygodnie po rozpoczęciu leczenia)

Laboratory tests showed mild macrocytic anae$\mathrm{mia}$, an elevated ESR $(30 \mathrm{~mm} / \mathrm{h})$ and the presence of antinuclear (ANA) antibodies identified by immunoblot analysis: anti-Ro52 ++ and anti-SS-A $(60 \mathrm{kDa})++$. Direct immunofluorescence examination of pathologically altered skin and normal skin from the gluteal region failed to demonstrate $\mathrm{IgG}$, IgA, IgM, C1q or C3c deposits. Histopathological analysis demonstrated marked thinning of the epidermis and orthokeratosis. The basal layer of the pleców obserwowano zlewne, ostro odgraniczone, rumieniowo-naciekowe zmiany skórne o układzie obrączkowatym (ryc. 1). Zmianom towarzyszył nasilony świąd skóry (7/10 wg skali numerycznej). Według pacjentki zmiany zaostrzały się po ekspozycji na światło słoneczne.

W badaniach laboratoryjnych stwierdzono nieznaczną anemię makrocytarną, przyspieszony $\mathrm{OB}(30 \mathrm{~mm})$ oraz obecność przeciwciał przeciwjądrowych (ANA) w badaniu metodą immunoblot: anty-Ro52 ++ oraz anty-SS-A $(60 \mathrm{kDa})++$. W bezpośrednim badaniu im- 


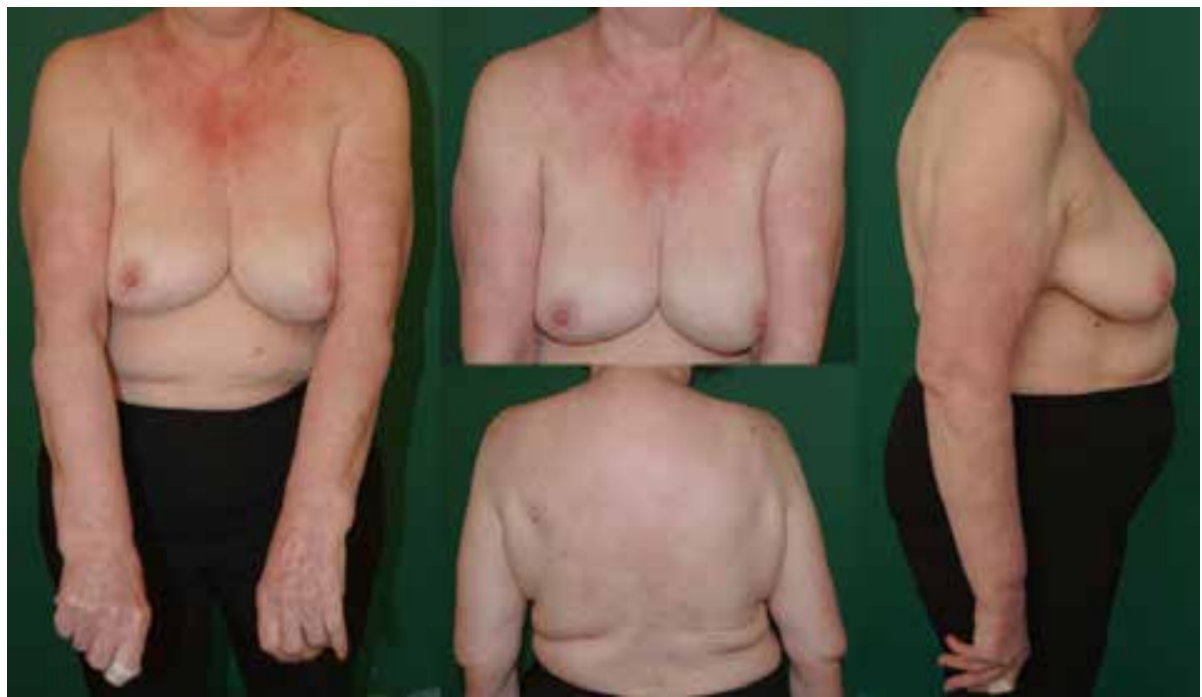

Figure 4. Significant improvement in skin condition (8 weeks after the initiation of treatment)

Rycina 4. Znaczna poprawa stanu miejscowego skóry (8 tygodni po rozpoczęciu leczenia)

epidermis revealed features of vacuolar degeneration and isolated cytoid bodies. The dermis was affected by a relatively abundant, diffuse perivascular lymphocytic infiltrate (fig. 2). The findings were considered to be indicative of the spectrum of lupus erythematosus.

Based on the patient's history, clinical picture and results of additional tests, drug-induced SCLE was diagnosed. Amlodipine was suspected as a causative agent and after consultation with a cardiologist the drug was discontinued. Following consultation with an ophthalmologist, treatment with chloroquine at a dose of $500 \mathrm{mg} /$ day for 5 days a week (with a weekend break) was initiated. Topical therapy was based on formulations containing mometasone furoate (cream $0.1 \%$ once daily) and prednisolone (ointment $0.5 \%$ twice daily). During a 14-day hospitalization, a significant improvement in the skin condition (fig. 3) and a decrease in pruritus (NRS score 2/10) were achieved.

Eight weeks later the patient presented for a follow-up visit, during which only mildly pronounced hyperpigmentations were present in the location previously affected by annular erythematous lesions, and poorly marginated erythema on the skin of the décolletage (fig. 4). A follow-up blood test demonstrated a lower titre of anti-Ro52 antibodies.

\section{DISCUSSION}

In 1985 Reed et al. [10] first described a case of drug-induced subacute cutaneous lupus erythematosus (DI-SCLE) in 5 patients in whom papular scaly lesions in a photodistributed pattern typical of SCLE together with anti-Ro/SS-A antibodies appeared munofluorescencyjnym zarówno skóry zmienionej chorobowo, jak i niezmienionej skóry pośladka nie wykazano obecności złogów IgG, IgA, IgM, C1q i C3c. W badaniu histopatologicznym stwierdzono znaczne ścieńczenie naskórka i ortokeratozę. W strefie warstwy podstawnej naskórka widoczne były cechy zwyrodnienia wodniczkowego oraz pojedyncze ciałka cytoidalne. W skórze właściwej wykazano stosunkowo obfity, rozproszony, okołonaczyniowy naciek limfocytarny (ryc. 2). Obraz oceniono jako będący w spektrum tocznia rumieniowatego.

Na podstawie wywiadu, obrazu klinicznego i wyników badań dodatkowych rozpoznano SCLE. Amlodypinę wytypowano jako podejrzany czynnik sprawczy i po konsultacji kardiologicznej odstawiono. Po konsultacji okulistycznej rozpoczęto terapię chlorochiną w dawce $500 \mathrm{mg} /$ dobę przez 5 dni w tygodniu, z przerwą weekendową. W leczeniu miejscowym stosowano preparaty zawierające furoinian mometazonu (krem 0,1\% 1 raz dziennie) i prednizolon (maść 0,5\% 2 razy dziennie). W czasie 14-dniowej hospitalizacji uzyskano znaczną poprawę stanu miejscowego (ryc. 3) oraz zmniejszenie nasilenia świądu (2/10 wg skali numerycznej).

Po 8 tygodniach pacjentka zgłosiła się na wizytę kontrolną, w trakcie której obserwowano jedynie nieznacznie nasilone przebarwienia w miejscu wcześniej występujących skórnych zmian rumieniowo-obrączkowatych oraz nieostro odgraniczony rumień na skórze klatki piersiowej w okolicy mostka (ryc. 4). W kontrolnym badaniu krwi stwierdzono zmniejszenie miana przeciwciał anty-Ro52.

\section{OMÓWIENIE}

W 1985 r. Reed i wsp. [10] po raz pierwszy opisali przypadek polekowego podostrego skórnego tocznia rumieniowatego (drug-induced cutaneous lupus erythematosus 
during the treatment with hydrochlorothiazide. The skin lesions resolved after the drug was discontinued [11-14].

DI-SCLE is considered to be the most common variant of drug-induced lupus erythematosus. Other variants include drug-induced systemic lupus erythematosus (DI-SLE) and drug-induced chronic cutaneous lupus erythematosus (DI-CCLE) [11]. DI-SCLE is clinically, serologically, immunologically and histopathologically similar to idiopathic SCLE, however there is a range of features differentiating the two nosological entities [13]. In DI-SCLE the mean age of disease onset is higher (approximately 58 years), which is probably linked to the more common use of medications amongst this age group. The disease occurs slightly more frequently in women than in men $[6,13,14]$. Similarly to idiopathic SCLE, the clinical features of DI-SCLE include polycyclic annular or papular scaly skin lesions located in sunlight-exposed areas, however DI-SCLE is more frequently associated with extensive skin involvement, especially of the lower extremities (including purpuric or ulcerative/necrotic lesions typical of cutaneous smallvessel vasculitis), facial involvement, development of bullous lesions and skin symptoms resembling erythema multiforme (Rowell syndrome). However, the involvement of internal organs and evolution to SLE are less commonly observed [11]. Serological markers of DI-SCLE include anti-Ro/SS-A antibodies, occasionally coexisting with anti-La/SS-B antibodies. Conversely, anti-histone antibodies (AHA), typically associated with DI-SLE, rarely accompany DI-SCLE (20-40\%) and cannot be regarded as a serological marker of the condition $[6,15]$. There are no differences between SCLE and DI-SCLE in terms of histopathological findings and DIF results [13].

DI-SCLE develops as a result of exposure to certain drugs, usually hypotensive agents: calcium channel blockers (CCBs), diuretics, angiotensin-converting-enzyme inhibitors, $\beta$-blockers and antifungal medications (chiefly terbinafine) [12]. Common causative factors also include proton pump inhibitors, ticlopidine and chemotherapeutics (typically taxanes) [16, 17], and less commonly antihistamines and statins [15]. The period between the initiation of drug therapy and the onset of pathological lesions (i.e. incubation period) depends on the type of drug used and ranges from a few days up to a few years.

Among medications used in the treatment of arterial hypertension, CCBs and thiazide diuretics are most commonly reported as the causative factors of DI-SCLE [15]. Both dihydropyridine and nondihydropyridine CCBs are responsible for inducing DI-SCLE, however the vast majority of reported cases are attributed to verapamil and diltiazem, and rarely to nifedipine and nitrendipine. Only one case
- DI-SCLE) u 5 pacjentów, u których zmiany grudkowo-złuszczające w typowej dla SCLE fotodystrybucji wraz $\mathrm{z}$ przeciwciałami anty-Ro/SS-A pojawiły się w trakcie stosowania hydrochlorotiazydu. Zmiany skórne ustąpiły po odstawieniu leku [11-14].

DI-SCLE jest uznawany za najczęstszą odmianę polekowego tocznia rumieniowatego, która obejmuje ponadto polekowy toczeń rumieniowaty układowy (drug-induced systemic lupus erythematosus - DI-SLE) oraz polekowy przewlekły skórny toczeń rumieniowaty (drug-induced chronic cutaneous lupus erythematosus - DI-CCLE) [11]. DI-SCLE jest klinicznie, serologicznie, immunologicznie oraz histopatologicznie podobny do idiopatycznego SCLE, można jednak wyróżnić szereg cech różnicujących te dwie jednostki chorobowe [13]. W przypadku DI-SCLE średni wiek wystąpienia choroby jest wyższy i wynosi ok. 58 lat. Prawdopodobnie ma to związek z częstszym stosowaniem leków w tej grupie wiekowej. Choroba występuje nieznacznie częściej u kobiet [6, 13, 14]. W obrazie klinicznym podobnie jak w idiopatycznym SCLE obserwuje się policykliczne, obrączkowate lub grudkowo-złuszczające zmiany skórne w miejscach eksponowanych na światło słoneczne, jednak w przebiegu DI-SCLE częściej dochodzi do rozległego zajęcia skóry, zwłaszcza kończyn dolnych (w tym zmian o typie zapalenia małych naczyń skóry - plamiczych lub martwiczo-wrzodziejących), zajęcia skóry twarzy, powstawania zmian pęcherzowych oraz zmian przypominających rumień wielopostaciowy (tzw. zespół Rowella). Z kolei rzadziej następuje zajęcie narządów wewnętrznych oraz ewolucja w kierunku SLE [11]. Markerem serologicznym DI-SCLE są również przeciwciała anty-Ro/SS-A, które niekiedy współistnieją z przeciwciałami anty-La/SS-B. Natomiast przeciwciała przeciwhistonowe (anti-histone antibodies - AHA), typowe dla DI-SLE rzadko występują w przebiegu DI-SCLE (20-40\%) i nie mogą być uznane za jego marker serologiczny [6, 15]. Obraz histologiczny oraz DIF nie wykazują różnic między SCLE i DI-SCLE [13].

Do rozwoju DI-SCLE dochodzi wskutek ekspozycji na niektóre leki, najczęściej przeciwnadciśnieniowe: inhibitory kanału wapniowego (calcium channel blockers - CCB), diuretyki, inhibitory konwertazy angiotensyny, $\beta$-adrenolityki, oraz leki przeciwgrzybicze (przede wszystkim terbinafinę) [12]. Częstym czynnikiem sprawczym są również inhibitory pompy protonowej, tiklopidyna i chemioterapeutyki (najczęściej taksany) [16, 17], a rzadziej leki przeciwhistaminowe i statyny [15]. Czas między rozpoczęciem stosowania leku a pojawieniem się zmian chorobowych (tzw. okres inkubacji) zależy od rodzaju zażywanego leku i wynosi od kilku dni do nawet kilku lat.

Spośród leków stosowanych w leczeniu nadciśnienia tętniczego CCB oraz diuretyki tiazydowe są najczęściej opisywane jako czynnik sprawczy DI-SCLE [15]. Zarówno dihydropirydynowe, jak i niedihydropirydynowe CCB odpowiadają za indukcję DI-SCLE, jednak więk- 
of amlodipine-induced DI-SCLE has been reported to date. A 62-year-old man developed psoriasiform erythematous lesions on the skin of the arms and chest 4 weeks after the introduction of amlodipine treatment [7]. Also, in the study by Hillesheim et al. [12], describing 15 cases of DI-SCLE, concurrent use of benazepril and amlodipine was recognized as the causative factor in one of the patients. It needs to be noted, though, that both papers referred to above failed to provide information on amlodipine doses, and the second one did not specify the duration of treatment.

Determining the causative factor of DI-SCLE in patients who chronically use drugs from various therapeutic classes is not an easy task, particularly when simple discontinuation of suspected drugs is not possible on account of the patient's coexisting medical disorders. In order to identify the causative factor in such cases, it is recommended to thoroughly analyze all drugs taken by the patient with a focus on their potential to induce DI-SCLE and the period until the onset of the disease. All drugs which are not essential for the patient should be discontinued [13].

Amlodipine was identified as the causative factor out of all drugs used by our patient on the basis of a range of criteria. Firstly, amlodipine was the last drug introduced into the patient's therapy. Secondly, drugs from the CCB class are characterized by one of the longest reported incubation periods ranging from 3 weeks to 6 years $[15,18]$. The incubation periods documented so far for $\beta$-blockers and statins vary from 1 week to 2 months and from 10 weeks to 2 years, respectively. Consequently, it was possible to eliminate metoprolol and atorvastatin, which had been used by the patient for approximately 5 years, from the list of suspected drugs. Although angiotensin-converting-enzyme inhibitors (ACEIs) have been repeatedly reported as DI-SCLE-inducing drugs, to the best knowledge of the authors there are no similar publications on angiotensin II receptor blockers (ARB), including valsartan which was taken by our patient. However, it must be noted that the incubation period of ACEIs ranges from 6 weeks to 6 months. Consequently, even assuming a certain degree of analogy between the two drug classes in their DI-SCLE induction potential, ARB can be ruled out as a suspected trigger in the case of our patient.

The cornerstones of therapeutic management in DI-SCLE continue to include the discontinuation of the causative drug and photoprotection [19]. During the period of active skin lesions it is also recommended to introduce a short-term symptomatic treatment with systemic glucocorticosteroids. Hydroxychloroquine can be used as adjuvant therapy. Symptomatic topical treatment is based on glucocorticosteroid medications or tacrolimus $[6,20,21]$. The severity szość opisanych przypadków dotyczy werapamilu i diltiazemu, rzadko nifedypiny i nitrendypiny. Dotychczas opisano jeden przypadek DI-SCLE indukowanego amlodypiną. U 62-letniego mężczyzny łuszczycopodobne zmiany rumieniowe na skórze ramion i klatki piersiowej pojawiły się 4 tygodnie po rozpoczęciu stosowania tego leku [7]. Z kolei Hillesheim i wsp. [12] opisali 15 przypadków DI-SCLE, spośród których u jednego z pacjentów za czynnik sprawczy uznano jednoczesne stosowanie benazeprilu i amlodypiny. Należy podkreślić, że w obu przytoczonych publikacjach nie podano dawek amlodypiny, a w ostatniej również czasu trwania terapii.

U pacjentów przewlekle stosujących leki z różnych grup terapeutycznych ustalenie czynnika sprawczego DI-SCLE nie jest łatwym zadaniem, zwłaszcza gdy obciążenia internistyczne pacjenta nie pozwalają na swobodne odstawianie podejrzanych leków. W takim przypadku w celu wytypowania czynnika sprawczego wskazane jest dokładne przeanalizowanie stosowanych przez pacjenta leków pod kątem ich potencjału oraz czasu do wyindukowania DI-SCLE. Należy odstawić wszystkie leki, które nie są pacjentowi niezbędne [13].

Spośród leków stosowanych przez naszą pacjentkę amlodypina została wytypowana jako czynnik sprawczy na podstawie kilku kryteriów. Przede wszystkim była lekiem włączonym najpóźniej. Ponadto leki z grupy CCB cechują się jednym z najdłuższych opisanych okresów inkubacji, wynoszącym od 3 tygodni do 6 lat $[15,18]$. Dla $\beta$-adrenolityków potwierdzony dotychczas okres inkubacji wynosi od 1 tygodnia do 2 miesięcy, natomiast dla statyn od 10 tygodni do 2 lat, co pozwoliło na wyeliminowanie stosowanych przez pacjentkę od ok. 5 lat metoprololu oraz atorwastatyny z listy podejrzanych leków. Mimo że niejednokrotnie udokumentowano przypadki DI-SCLE indukowanego przez inhibitory konwertazy angiotensyny (angiotensin converting enzyme inhibitors - ACEI), to podobne publikacje dotyczące inhibitorów receptora angiotensyny II (angiotensin II receptor blockers - ARB), w tym stosowanego przez pacjentkę walsartanu, wg wiedzy autorów nie są obecnie dostępne. Warto jednak dodać, że okres inkubacji dla ACEI wynosi od 6 tygodni do 6 miesięcy, co nawet przy założeniu pewnego podobieństwa w zakresie potencjału wyzwalającego DI-SCLE w przypadku obu tych grup leków pozwala wyeliminować u naszej pacjentki ARB z kręgu podejrzeń.

Podstawą postępowania terapeutycznego w DI-SCLE jest zaprzestanie stosowania leku będącego czynnikiem sprawczym oraz fotoprotekcja [19]. Ponadto w okresie aktywnych zmian skórnych wskazane jest krótkoterminowe leczenie objawowe przy zastosowaniu ogólnie glikokortykosteroidów. Wspomagająco można dołączyć hydroksychlorochinę. W objawowym leczeniu miejscowym stosuje się preparaty glikokortykosteroidowe lub takrolimus $[6,20,21]$. W czasie kilku tygodni zmniejsza się na- 
of skin lesions is reduced during a few weeks, however a complete remission usually requires several months. After achieving a partial improvement in the topical condition and reducing the severity of skin eruptions adjuvant symptomatic therapy can be discontinued [14]. Other immunosuppressive drugs (azathioprine, cyclophosphamide or mycophenolate mofetil) can be considered in treatment-refractory cases. In $40 \%$ of patients with anti-Ro/SS-A antibodies the titre decreases after approximately 8 months of therapy [19].

\section{CONCLUSIONS}

When determining the aetiopathogenesis of SCLE, medications should be considered as a possible causative factor in all cases of the disease, particularly in patients over 50 years of age. A detailed analysis of drugs taken by such patients is advisable to assess the potential of the drugs to induce lesions and the time frame until the appearance of symptoms. This is particularly important in patients taking cardiac drugs including CCBs. Even though within this drug class the causative role is usually attributed to nondihydropyridine derivatives, another possibility to consider is the induction of changes by dihydropyridine derivatives including amlodipine.

\section{CONFLICT OF INTEREST}

The authors declare no conflict of interest. silenie zmian skórnych, natomiast czas do pełnej remisji wynosi zazwyczaj kilka miesięcy. Po osiągnięciu częściowej poprawy stanu miejscowego i zmniejszenia nasilenia wykwitów skórnych wspomagające leczenie objawowe może zostać odstawione [14]. W przypadkach opornych na leczenie można rozważyć zastosowanie innych leków immunosupresyjnych, takich jak azatiopryna, cyklofosfamid lub mykofenolan mofetylu. U 40\% pacjentów z przeciwciałami anty-Ro/ SS-A obserwuje się zmniejszenie ich miana po ok. 8 miesiącach [19].

\section{WNIOSKI}

We wszystkich przypadkach SCLE należy rozważyć w etiopatogenezie choroby tło polekowe, zwłaszcza u pacjentów po 50. roku życia. U tych chorych wskazane jest dokładne przeanalizowanie stosowanych leków pod kątem ich potencjału oraz czasu wyzwalania objawów. Jest to szczególnie istotne u pacjentów stosujących leki kardiologiczne, włączając w to CCB. Mimo że w obrębie tej grupy leków rolę sprawczą najczęściej przypisuje się pochodnym niedihydropirydynowym, należy również uwzględnić możliwość indukcji zmian przez pochodne dihydropirydynowe, $\mathrm{w}$ tym amlodypinę.

\section{KONFLIKT INTERESÓW}

Autorzy nie zgłaszają konfliktu interesów.

\section{References}

Piśmiennictwo

1. Sontheimer R.D., Thomas J.R., Gilliam J.N.: Subacute cutaneous lupus erythematosus: a cutaneous marker for a distinct lupus erythematosus subset. Arch Dermatol 1979, 115, 1409-1415.

2. Hughes R., Loftus B., Kirby B.: Subacute cutaneous lupus erythematosus presenting as poikiloderma. Clin Exp Dermatol 2009, 34, 859-861.

3. Lee H.J., Sinha A.A.: Cutaneous lupus erythematosus: understanding of clinical features, genetic basis, and pathobiology of disease guides therapeutic strategies. Autoimmunity 2006, 39, 433-444.

4. Durosaro O., Davis M.D.P., Reed K.B., Rohlinger A.L.: Incidence of cutaneous lupus erythematosus, 1965-2005. Arch Dermatol 2009, 145, 249-253.

5. Sontheimer R.D.: Subacute cutaneous lupus erythematosus: 25-year evolution of a prototypic subset (subphenotype) of lupus erythematosus defined by characteristic cutaneous, pathological, immunological, and genetic findings. Autoimmun Rev 2005, 4, 253-263.

6. Marzano A.V., Vezzoli P., Crosti C.: Drug-induced lupus: an update on its dermatologic aspects. Lupus 2009, 18, 935-940.

7. Ortega-Loayza A.G., McCall C.O., Cooke R.H., Jovin I.S.: Amlodipine-induced subacute cutaneous lupus. N Am J Med Sci 2013, 5, 246-247.

8. Rothfield N., Sontheimer R.D., Bernstein M.: Lupus erythematosus: systemic and cutaneous manifestations. Clin Dermatol 2006, 24, 348-362.

9. Reich A., Marcinów K., Białynicki-Birula R.: The lupus band test in systemic lupus erythematosus patients. Ther Clin Risk Manag 2011, 7, 27-32.

10. Reed B.R., Huff J.C., Jones S.K., Orton P.W., Lee L.A., Norris D.A.: Subacute cutaneous lupus erythematosus associated with hydrochlorothiazide therapy. Ann Intern Med 1985, 103, 49-51.

11. Marzano A.V., Lazzari R., Polloni I., Crosti C., Fabbri P., Cugno M.: Drug-induced subacute cutaneous lupus erythematosus: evidence for differences from its idiopathic counterpart. Br J Dermatol 2011, 165, 335-341. 
12. Hillesheim P.B., Bahrami S., Jeffy B.G., Callen J.P.: Tissue eosinophilia: not an indicator of drug-induced subacute cutaneous lupus erythematosus. Arch Dermatol 2012, 148, 190-193.

13. Lowe G.C., Henderson C.L., Grau R.H., Hansen C.B., Sontheimer R.D.: A systematic review of drug-induced subacute cutaneous lupus erythematosus. Br J Dermatol 2011, 164, 465-472.

14. Sontheimer R.D., Henderson C.L., Grau R.H.: Drug-induced subacute cutaneous lupus erythematosus: a paradigm for bedside-to-bench patient-oriented translational clinical investigation. Arch Dermatol Res 2009, 301, 65-70.

15. Szczęch J., Samotij D., Werth V.P., Reich A.: Trigger factors of cutaneous lupus erythematosus: a review of current literature. Lupus 2017, 26, 791-807.

16. Reich A., Maj J.: Subacute cutaneous lupus erythematosus due to proton pump inhibitor intake: case report and literature review. Arch Med Sci 2012, 8, 743-747.

17. Reich A., Białynicki-Birula R., Szepietowski J.C.: Drug-induced subacute cutaneous lupus erythematosus resulting from ticlopidine. Int J Dermatol 2006, 45, 1112-1114.

18. Crowson A.N., Magro C.M.: Subacute cutaneous lupus erythematosus arising in the setting of calcium channel blocker therapy. Hum Pathol 1997, 28, 67-73.

19. Srivastava M., Rencic A., Diglio G., Santana H., Bonitz P., Watson R., et al.: Drug-induced, Ro/SSA-positive cutaneous lupus erythematosus. Arch Dermatol 2003, 139, 45-49.

20. Aggarwal N.: Drug-induced subacute cutaneous lupus erythematosus associated with proton pump inhibitors. Drugs Real World Outcomes 2016, 3, 145-154.

21. Kurtis B., Larson M.J., Hoang M.P., Cohen J.B.: Case report: verapamil-induced subacute cutaneous lupus erythematosus. J Drugs Dermatol 2005, 4, 506-508.

Received: 18.12 .2017

Accepted: 28.01.2018

Otrzymano: $18.12 .2017 \mathrm{r}$.

Zaakceptowano: 28.01 .2018 r.

How to cite this article

Kozłowska A., Woźniak Z., Maj J., Białynicki-Birula R.: Drug-induced subacute cutaneous lupus erythematosus caused by amlodipine. Dermatol Rev/Przegl Dermatol 2018, 105, 298-306. DOI: https://doi.org/10.5114/dr.2018.75585. 